OPEN ACCESS

Edited by:

Martin C. Michel,

Johannes Gutenberg University Mainz,

Germany

Reviewed by:

Finn Olav Levy,

University of Oslo, Norway

Jan Matthes,

University of Cologne, Germany

${ }^{*}$ Correspondence: Wenkuan Xin

xinwenkuan@swu.edu.cn

Specialty section: This article was submitted to Cardiovascular and Smooth Muscle Pharmacology, a section of the journal Frontiers in Pharmacology

Received: 22 August 2019 Accepted: 19 May 2020

Published: 05 June 2020

Citation:

Zhao J, Wang Y, Gao J, Jing Y and Xin W (2020) Berberine Mediated Positive Inotropic Effects on Rat Hearts via a $\mathrm{Ca}^{2+}$-Dependent Mechanism.

Front. Pharmacol. 11:821. doi: 10.3389/fphar.2020.00821

\section{Berberine Mediated Positive Inotropic Effects on Rat Hearts via a $\mathrm{Ca}^{2+}$-Dependent Mechanism}

\author{
Junli Zhao, Yaqian Wang, Jie Gao, Yang Jing and Wenkuan Xin * \\ College of Pharmaceutical Sciences, Southwest University, Chongqing, China
}

Previous studies showed that berberine, an alkaloid from Coptis Chinensis Franch, might exert a positive inotropic effect on the heart. However, the underlying mechanisms were unclear. Here, we reported that berberine at 10-20 $\mu \mathrm{M}$ increased the left ventricular (LV) developed pressure and the maximal rate of the pressure rising, and it increased the maximal rate of the pressure descending at $20 \mu \mathrm{M}$ in Langendorff-perfused isolated rat hearts. These effects diminished with the concentration of berberine increasing to $50 \mu \mathrm{M}$. In the concentration range of $50-300 \mu \mathrm{M}$, berberine increased the isometric tension of isolated left ventricular muscle (LVM) strips with or without electrical stimulations, and it (30-300 $\mu \mathrm{M})$ also increased the intracellular $\mathrm{Ca}^{2+}$ level in the isolated LV myocytes. The removal of extracellular $\mathrm{Ca}^{2+}$ hindered the berberine-induced increases in the tension of LVM strips and the intracellular $\mathrm{Ca}^{2+}$ level of LV myocytes. These suggested that berberine might exert its positive inotropic effects via enhancing $\mathrm{Ca}^{2+}$ influx. The blockade of $\mathrm{L}$-type $\mathrm{Ca}^{2+}$ channels (LTCCS) with nifedipine significantly attenuated $300 \mu \mathrm{M}$ berberine-induced tension increase in LVM strips but not the increase in the intracellular $\mathrm{Ca}^{2+}$ level. Berberine (300 $\mu \mathrm{M}$ ) further increased the LVM tension following the treatment with the LTCC opener FPL-64716 $(10 \mu \mathrm{M})$, indicating an LTCC-independent effect of berberine. Lowering extracellular $\mathrm{Na}^{+}$attenuated the berberine-induced increases in both the tension of LVM strips and the intracellular $\mathrm{Ca}^{2+}$ level of LV myocytes. In conclusion, berberine might exert a positive inotropic effect on the isolated rat heart by enhancing the $\mathrm{Ca}^{2+}$ influx in LV myocytes; these were extracellular $\mathrm{Na}^{+}$-dependent.

Keywords: berberine, heart, positive inotropic effect, $\mathrm{Ca}^{2+}, \mathrm{Na}^{+}$

Abbreviations: HEPES, 4-(2-hydroxyethyl)-1-piperazinethanesulfonic acid; K-B, Kraft-Brühe; K-H, Krebs-Henseleit; LTCC, L-type $\mathrm{Ca}^{2+}$ channel; LV, left ventricular; LVDP, left ventricular developed pressure; LVEDP, left ventricular end-diastolic pressure; LVM, left ventricular muscle; LVP, left ventricular pressure; LVSP, left ventricular systolic pressure; NMDG, NMethyl-D-glucamine; $\mathrm{NCX}, \mathrm{Na}^{+} / \mathrm{Ca}^{2+}$ exchanger. 


\section{INTRODUCTION}

Berberine is an alkaloid present in numerous plants, including Coptis Chinensis Franch, and has been used for the treatment of gastrointestinal infections and diarrhea in Asian countries, particularly in China. The interest in its beneficial effects on significant risk factors of cardiovascular diseases has been growing over the last two decades (Lau et al., 2001; Zeng et al., 2003; Yuan et al., 2006; Affuso et al., 2010; Sola et al., 2014).

Berberine increased the developed force in the isolated left atrium of guinea pigs by enhancing both the force-velocity relationship and the duration of the active state (Shaffer, 1985). The contractile capability of the left ventricle is critical for heart function. As the left ventricle contracts, the pressure rises to a level that is high enough to pump blood into systemic circulation through the aorta (Bombardini, 2005). However, there is no study about the berberine effect on the LV contractility, which is vital for the pumping capability of the heart, and the underlying mechanisms by which berberine affects the left ventricle remains to be determined.

In LV myocytes, the $\mathrm{Ca}^{2+}$ entry through LTCCs triggers $\mathrm{Ca}^{2+}$ release from the sarcoplasmic reticulum into the cytoplasm. These consequently increase the intracellular $\mathrm{Ca}^{2+}$ level and cause LV myocytes shortening, which provides the force for the ejection of blood (Bers, 2002; Eisner et al., 2017; Gilbert et al., 2020). In addition to the $\mathrm{Ca}^{2+}$ influx through LTCCs, $\mathrm{Ca}^{2+}$ also enters the cell through an LTCC-independent pathway (Kiang and Smallridge, 1994; Tang et al., 1998). The $\mathrm{Na}^{+} / \mathrm{Ca}^{2+}$ exchanger (NCX) is the dominant transporter mediating $\mathrm{Ca}^{2+}$ efflux (Blaustein and Lederer, 1999; Philipson and Nicoll, 2000; Bers, 2002). The $\mathrm{Na}^{+}$influx during the early phase of an action potential induces $\mathrm{Ca}^{2+}$ influx via the reverse mode of NCX, which consequently induces the $\mathrm{Ca}^{2+}$ release from the sarcoplasmic reticulum and the elevation of intracellular $\mathrm{Ca}^{2+}$ level (Larbig et al., 2010; Yan et al., 2015).

In this study, we utilized Langendorff-perfused heart recordings, isometric tension recordings, and confocal microscopy techniques to investigate the effects of berberine on the LV contractility and the underlying mechanisms. Our study revealed that berberine elevated the intracellular $\mathrm{Ca}^{2+}$ level of $\mathrm{LV}$ myocytes via increasing $\mathrm{Ca}^{2+}$ influx. It consequently increased the LV contractility. These were extracellular $\mathrm{Na}^{+}$-dependent.

\section{MATERIALS AND METHODS}

\section{Ethics Statement}

We carried out the animal procedures following The Guide for the Care and Use of Laboratory Animals of the National Institutes of Health, and the Institutional Animal Ethics Committee of Southwest University approved all the procedures.

\section{Animal Housing, Euthanasia, and Isolated Heart Harvesting}

Adult male Sprague-Dawley rats (200-300 g) were purchased from Da Ping Hospital (Chongqing, China, SCXK 2017-0005) and were housed at Southwest University (Chongqing, China, SYXK 2014-0002). All rats were exposed to $12 / 12 \mathrm{~h}$ light/dark cycles at room temperature $\left(24 \pm 2^{\circ} \mathrm{C}\right)$ and were free to food and water. Rats were euthanized by $\mathrm{CO}_{2}$ inhalation or sodium pentobarbital injection (60 $\mathrm{mg} / \mathrm{kg}$ body weight, ip), and the hearts were then quickly removed from the thoracic cavity by thoracotomy.

\section{Langendorff-Perfused Isolated Heart Recordings}

Langendorff-perfused isolated heart recordings were carried out as previously described (Carre et al., 2014; Tilley et al., 2014). Briefly, rats were anesthetized with sodium pentobarbital (60 $\mathrm{mg} / \mathrm{kg}$ body weight, ip), and the heart was rapidly excised by thoracotomy and then cannulated through the aorta. The isolated heart was mounted on a Langendorff apparatus (DMT MyoHEART 900MH System, Aarhus, Denmark) under a constant perfusion pressure $(70 \mathrm{mmHg})$ and perfused with Krebs-Hensseleit (K-H) buffer saturated with a 95\% $\mathrm{O}_{2} / 5 \%$ $\mathrm{CO}_{2}$ mixture, yielding a final $\mathrm{pH}$ of 7.4 at $37^{\circ} \mathrm{C}$. For assessment of the performance of the left ventricle, a balloon connected to a pressure transducer was inserted into the left ventricle. It was used to set the left ventricular end-diastolic pressure (LVEDP) at 5-10 $\mathrm{mmHg}$. After a 30-min stabilization period, berberine was added to the perfusion buffer with accumulative concentrations. Left ventricular systolic pressure (LVSP), LVEDP, LVDP (defined as LVDP = LVSP - LVEDP), the maximal rates of LVDP rising and descending during isovolumetric contraction and relaxation $\left(+d p / d t_{\max }\right.$ and $\left.|-d p / d t|_{\max }\right)$ were analyzed with LabChart 8.1.5 (ADInstruments, Australia).

\section{Isometric Tension Recordings}

Isometric tension recordings in LVM strips were performed as previously described (Uhl et al., 2015). Briefly, the isolated hearts were transferred to the oxygenated $\mathrm{K}-\mathrm{H}$ buffer containing $30 \mathrm{mM}$ 2,3-butanedione monoxime ( $\mathrm{pH} 7.4)$ at $4^{\circ} \mathrm{C}$. LVM strips of $1-2$ $\mathrm{mm}$ width, 1-1.5 $\mathrm{mm}$ thickness, and 6-8 $\mathrm{mm}$ length were prepared and mounted between metal clips attached to an anchoring hook and a force transducer in temperaturecontrolled $\left(37^{\circ} \mathrm{C}\right)$ chambers filled with $10 \mathrm{ml} \mathrm{K}-\mathrm{H}$ buffer and continuously bubbled with a $95 \% \mathrm{O}_{2} / 5 \% \mathrm{CO}_{2}$ mixture (DMT 750BTOS Tissue Organ bath system, Aarhus, Denmark). The strips were electrically driven with rectangular pulses $(2 \mathrm{~ms}$, $0.1 \mathrm{~V}, 1 \mathrm{~Hz}$ ) using a CS4 stimulator (DMT instrument, Denmark). Pre-load was applied until the tension reached 5 $\mathrm{mN}$, and then LVM strips were washed with fresh $\mathrm{K}-\mathrm{H}$ buffer every 15 min during an equilibration period of $1 \mathrm{~h}$. The contraction of LVM strips was induced by epinephrine (10 $\mu \mathrm{M})$ or EFS $(5 \mathrm{~V}, 1 \mathrm{~Hz})$. Each berberine-treated strip had its vehicle control strip from the same ventricle.

\section{Left Ventricular Myocyte Isolation}

The LV myocytes of a rat were isolated as described previously (Carre et al., 2014; Roth et al., 2014). Briefly, the isolated hearts were rapidly excised, cannulated through the aorta and retrograde perfused $\left(5 \mathrm{ml} / \mathrm{min}, 37^{\circ} \mathrm{C}\right)$ with oxygenated $\mathrm{Ca}^{2+}$-free Tyrode's buffer using a Langendorff system (LGF-2C, Chengdu instrument, 
China). The heart was then perfused with nominally Tyrode's buffer containing collagenase II $(0.17 \mathrm{mg} / \mathrm{ml})$, collagenase IV $(0.10$ $\mathrm{mg} / \mathrm{ml})$, bovine serum albumin $(1.0 \mathrm{mg} / \mathrm{ml})$, and $50 \mu \mathrm{M} \mathrm{CaCl}$ until it became soft and spongy. The myocytes were mechanically dispersed and stored in the Kraft-Brühe (K-B) buffer. The concentration of $\mathrm{Ca}^{2+}$ was raised from $0.2 \mathrm{mM}$ to $1.5 \mathrm{mM}$ using a 4-step ladder. The freshly isolated cardiomyocytes were stored at room temperature $\left(25^{\circ} \mathrm{C}\right)$ for $\mathrm{Ca}^{2+}$ imaging.

\section{$\mathrm{Ca}^{2+}$ Imaging in Freshly Isolated Left Ventricular Myocytes}

The intracellular $\mathrm{Ca}^{2+}$ levels were monitored using a fluorescent calcium probe Fluo4-AM, as previously described (Chen et al., 2014). Briefly, freshly isolated cardiomyocytes were seeded in a dish coated with laminin and incubated for $30 \mathrm{~min}$ at $37^{\circ} \mathrm{C}$ to adhere to the bottom of the dish. The supernatant was removed, and cells were washed three times with a modified $\mathrm{K}-\mathrm{H}$ buffer, and then the cells were incubated with $5 \mu \mathrm{M}$ Fluo4-AM in the dark for $30 \mathrm{~min}$; the Fluo4-AM-containing buffer was then removed, and cells were washed three times with a modified $\mathrm{K}-\mathrm{H}$ buffer. The LV myocytes were imaged with the Nikon A1+ confocal microscope (Nikon, Tokyo, Japan) equipped with a 20X objective. The fluorescence intensity was detected with a $525 \pm 25 \mathrm{~nm}$ filter, and the excitation wavelength was $488 \mathrm{~nm}$. All $\mathrm{Ca}^{2+}$-imaging experiments were carried out at room temperature.

\section{Chemicals and Solutions}

Berberine chloride and sodium pentobarbital were purchased from Sigma-Aldrich (St. Louis, MO, the United States), and epinephrine bitartrate was from Adamas (Shanghai, China), and they were dissolved in deionized water. Nifedipine (SigmaAldrich, St. Louis, MO, the United States), FPL-64716 (Aladdin, Shanghai, China), and Fluo4-AM (Dojindo, Kyushu, Japan) were dissolved in DMSO, and the final concentration of DMSO in the buffer did not exceed $0.1 \%$. All other chemicals were purchased from Sigma-Aldrich (St. Louis, MO, the United States).

The K-H buffer for Langendorff-perfused rat heart recording was prepared freshly and contained the following (in $\mathrm{mM}$ ): $\mathrm{NaCl}$ 119.0, $\mathrm{NaHCO}_{3}$ 25.0, $\mathrm{KCl} 4.6, \mathrm{D}$-(+)-glucose 11.0, $\mathrm{CaCl}_{2} \cdot 2 \mathrm{H}_{2} \mathrm{O}$ $1.5, \mathrm{MgSO}_{4} \cdot 7 \mathrm{H}_{2} \mathrm{O} 1.6$, and $\mathrm{KH}_{2} \mathrm{PO}_{4}$ 1.2.

The K-H buffer for isometric tension recording experiment contained the following (in $\mathrm{mM}$ ): $\mathrm{NaCl} 119.0, \mathrm{NaHCO}_{3} 25.0$, $\mathrm{KCl} 4.6, \mathrm{D}$-(+)-glucose 11.0, $\mathrm{CaCl}_{2} \cdot 2 \mathrm{H}_{2} \mathrm{O} 1.5, \mathrm{MgSO}_{4} \cdot 7 \mathrm{H}_{2} \mathrm{O}$ 1.6, $\mathrm{KH}_{2} \mathrm{PO}_{4} 1.2$, and sodium pyruvate 1.0.

The $\mathrm{Ca}^{2+}$-free $\mathrm{K}-\mathrm{H}$ buffer was $\mathrm{K}-\mathrm{H}$ buffer, excluding $\mathrm{CaCl}_{2} \cdot 2 \mathrm{H}_{2} \mathrm{O}$ and containing $1 \mathrm{mM}$ ethylene glycol-bis (2aminoethylether)-N, N, N', N'-tetraacetic acid.

The $\mathrm{Cs}^{+}$-containing $\mathrm{Na}^{+}$-free $\mathrm{K}-\mathrm{H}$ buffer was prepared freshly and contained the following (in $\mathrm{mM}$ ): $\mathrm{CsCl}$ 119.0, $\mathrm{CsHCO}_{3}$ 25.0, $\mathrm{KCl} 5.8, \mathrm{D}-(+)$-glucose $11.0, \mathrm{CaCl}_{2} \cdot 2 \mathrm{H}_{2} \mathrm{O}$ 1.5, and $\mathrm{MgCl}_{2}$ 1.6.

The N-methyl-D-glucamine (NMDG)-containing $\mathrm{Na}^{+}$-free $\mathrm{K}-\mathrm{H}$ buffer contained (in mM): NMDG 119.0, $\mathrm{CsHCO}_{3}$ 25.0, $\mathrm{KCl} 5.8, \mathrm{D}-(+)$-glucose $11.0, \mathrm{CaCl}_{2} \cdot 2 \mathrm{H}_{2} \mathrm{O} 1.5$, and $\mathrm{MgCl}_{2}$ 1.6.

The $\mathrm{pH}$ of all buffers was adjusted to 7.40 with a $95 \% \mathrm{O}_{2} / 5 \%$ $\mathrm{CO}_{2}$ mixture except those explicitly indicated.
The nominally $\mathrm{Ca}^{2+}$-free Tyrode's buffer for the isolation of LV myocytes contained the following (in $\mathrm{mM}$ ): $\mathrm{NaCl} 140.0, \mathrm{KCl}$ 5.4, $\mathrm{MgCl}_{2}$ 1.0, D-(+)-glucose 10.0, and 4-(2-hydroxyethyl)-1piperazinethanesulfonic acid (HEPES) 10.0; $\mathrm{pH}$ was adjusted to 7.35 with $\mathrm{NaOH}$.

The K-B buffer for maintaining isolated LV myocytes contained the following (in $\mathrm{mM}$ ): $\mathrm{KOH} 80.0, \mathrm{KCl} 40.0$, Lglutamic acid 50.0, $\mathrm{KH}_{2} \mathrm{PO}_{4}$ 25.0, taurine 20.0, HEPES 10.0, ethylene glycol-bis (2-aminoethylether)-N, N, N', N'-tetraacetic acid 0.1, and $\mathrm{MgSO}_{4} 3.0, \mathrm{D}-(+)$-glucose $10.0 ; \mathrm{pH}$ was adjusted to 7.40 with $\mathrm{KOH}$.

The modified $\mathrm{K}-\mathrm{H}$ buffer for $\mathrm{Ca}^{2+}$ imaging experiments contained the following (in $\mathrm{mM}$ ): $\mathrm{NaCl} 125.0, \mathrm{KCl} 4.0, \mathrm{CaCl}_{2}$ 1.5, $\mathrm{MgCl}_{2}$ 1.0, D-(+)-glucose 10.0, HEPES 25.0, and $\mathrm{NaH}_{2} \mathrm{PO}_{4}$ 1.2; the $\mathrm{Ca}^{2+}$-free modified $\mathrm{K}-\mathrm{H}$ buffer was the modified $\mathrm{K}-\mathrm{H}$ buffer excluding $\mathrm{CaCl}_{2} \cdot 2 \mathrm{H}_{2} \mathrm{O}$ and containing $1 \mathrm{mM}$ ethylene glycol-bis (2-aminoethylether)-N, N, N', N'-tetraacetic acid; the low $\mathrm{Na}^{+}$modified $\mathrm{K}-\mathrm{H}$ buffer contained the following (in $\mathrm{mM}$ ): $\mathrm{NaCl}$ 62.5, NMDG 62.5, $\mathrm{KCl} 4.0, \mathrm{CaCl}_{2}$ 1.5, $\mathrm{MgCl}_{2}$ 1.0, D-(+)-glucose 1.0, HEPES 25.0, and $\mathrm{NaH}_{2} \mathrm{PO}_{4}$ 1.2; $\mathrm{pH}$ was adjusted to 7.30 with $12 \mathrm{mM} \mathrm{HCl}$.

All buffers were filtered through a membrane with a pore size of $0.22 \mu \mathrm{m}$.

\section{Data Analysis and Statistics}

LabChart 8.1.5 (ADInstruments, Australia) was used to analyze the parameters of perfused heart function and developed tension. NISElements 4.3 (Nikon, Japan) and Clampfit 10.5 (Molecular Devices, the United States) was used to analyze the intracellular $\mathrm{Ca}^{2+}$ level. The 5-min recordings before each addition of berberine were analyzed. The parameters were normalized to the recording before the first addition of berberine (taken as 100\%) in Langendorff-perfused heart recordings. The isolated LVM strip tension in the 5-min recording before the addition of any compound was taken as the basal level $(0 \%)$, and the effect of vehicle, berberine, or inhibitors was normalized to the basal level. The average fluorescence intensity in the last $3 \mathrm{~min}$ of the 15 -min perfusion of vehicle, berberine, or inhibitors was analyzed and normalized to that of the last 3-min recording with the modified K$\mathrm{H}$ buffer (taken as $100 \%$ ). Statistical analysis was performed with GraphPad Prism 7.02 (GraphPad Software, La Jolla, CA). All values are summarized as means \pm SEM; $n=$ the number of cells, LVM strips, and $\mathrm{N}=$ the number of rats. Statistical significance was performed with the two-way analysis of variance (ANOVA) with Sidak's multiple comparisons test or Tukey's multiple comparisons test, or the unpaired Student's t-test.

\section{RESULTS}

\section{Berberine Increased the Cardiac Contractility in Langendorff-Perfused Isolated Rat Hearts}

The Langendorff-perfused isolated-heart recordings provide information on heart functions without interference from the 
sympathetic nervous system (Bell et al., 2011). The isolated hearts were perfused for at least $30 \mathrm{~min}$ until they reached a stable state before the addition of berberine in the buffer (Figure 1A). The left ventricular pressure (LVP) wasW continuously recorded for at least $30 \mathrm{~min}$ at each concentration of berberine until it reached a stable level, which was defined as the variation of LVP amplitude was less than $10 \%$ within 5 min.

The LVDP, $+d p / d t_{\text {max }}$ and $|-d p / d t|_{\text {max }}$ are important parameters used for the evaluation of heart contractility (Jiang et al., 2014; Tilley et al., 2014; Huang et al., 2019). These three parameters increased following the perfusion of berberine $(10-20 \mu \mathrm{M})$ while they decreased with time in the absence of berberine (Figures 1B-D). Following the perfusion of berberine $(10 \mu \mathrm{M}), \mathrm{LVDP},+d p / d t_{\max }$, and $|-d p / d t|_{\max }$ increased to $129.0 \pm 11.4 \%, 112.3 \pm 8.0 \%$, and $110.0 \pm 9.3 \%$ of the basal levels, respectively; they decreased with time to 84.0 $\pm 5.8 \%, 83.1 \pm 4.8 \%$, and $81.5 \pm 5.8 \%$ of the basal levels in the absence of berberine, respectively. The results indicated that berberine could improve the heart function by enhancing contractility of the left ventricle. The LV contractility is crucial for heart function. Next, we investigated the effect of berberine on the contractile properties of LVM strips by using isometric tension recordings.

\section{Berberine Increased the Isometric Tension of LVM Strips of Rat Hearts}

In the isometric tension recordings, the initial tension of the strips was set to $5 \mathrm{mN}$, which declined with time; berberine reversed the decline and further increased the tension of LVM strips in a concentration-dependent manner. The isometric tension increased by $76.4 \pm 16.7 \%$ with the treatment of 100 $\mu \mathrm{M}$ berberine, while it decayed with time by $18.0 \pm 4.3 \%$ in the absence of berberine (Figure 2). These suggested that berberine can increase the contractile force of LV myocardium.

Epinephrine plays an essential role in the fight-or-flight response by increasing the output of the heart via the activation of $\beta$-adrenergic receptors. Under pathophysiological conditions, in the case of heart failure, the excessive activation of $\beta$-adrenergic receptors causes sustained elevation of cAMP, induces tachycardia and arrhythmic contractions, and increases cardiac workload (Galindo-Tovar and Kaumann, 2008; Johnson and Antoons, 2018). Epinephrine $(10 \mu \mathrm{M})$ induced phasic contractions in the isolated LVM strips. In the presence of epinephrine, the tension of LVM strips decreased with time, while the amplitude of the evoked phasic contractions did not change (Figure 3A). Following epinephrine, the subsequent addition of berberine increased the tension and eliminated the evoked phasic contractions in a concentration-dependent

A

\begin{tabular}{lcccc}
\multicolumn{4}{c}{ Ber } \\
\hline$\downarrow$ & $5 \mu \mathrm{M}$ & $10 \mu \mathrm{M}$ & $20 \mu \mathrm{M}$ & $50 \mu \mathrm{M}$
\end{tabular}
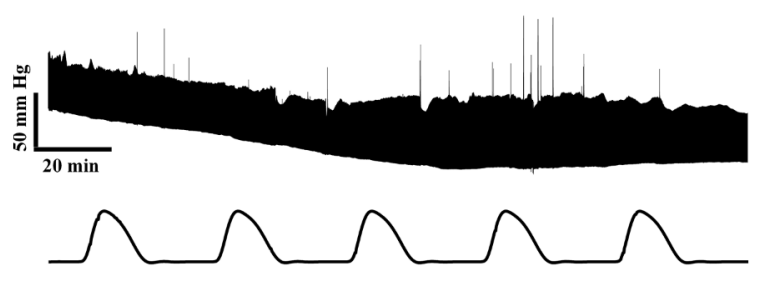

control
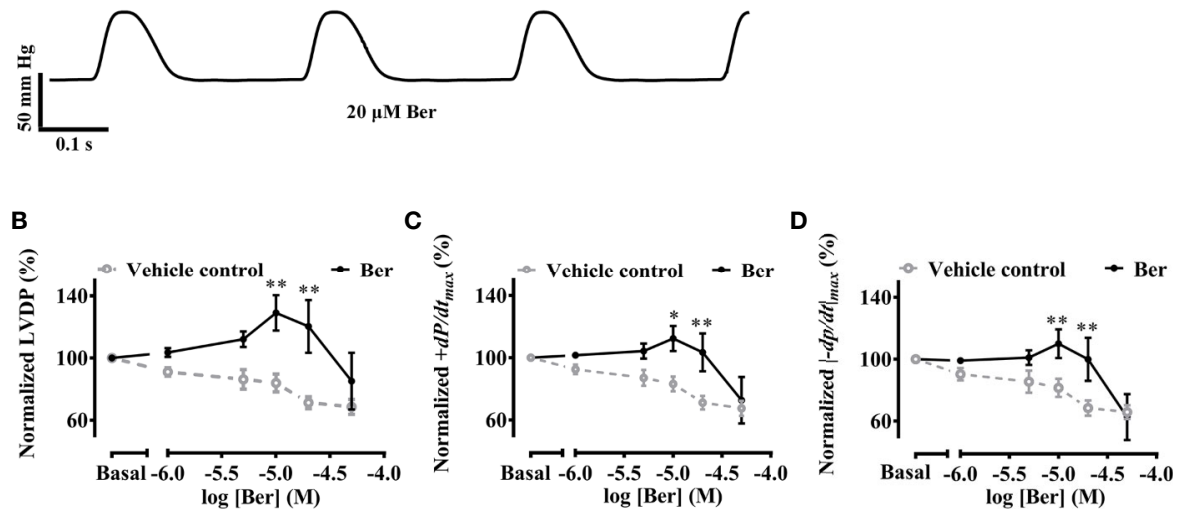

FIGURE 1 | Berberine increased the capability of Langendorff-perfused isolated rat hearts for contraction. (A) An original recording showing that the effect of berberine on left ventricular pressure (LVP) of an isolated rat heart. (B-D) Summary data showing the effects of berberine on LVDP, $+d p / d t_{\max }$ and $|-d p / d t|_{\max }$, respectively. The numbers of repeats are as follows: vehicle control group, $N=6$; Ber-treated group, $N=6$; $N$ is the number of rats. Ber stands for berberine. ${ }^{*} p<$ $0.05,{ }^{*} p<0.01$ vs. vehicle control group; two-way ANOVA with Sidak's multiple comparisons test. 
A

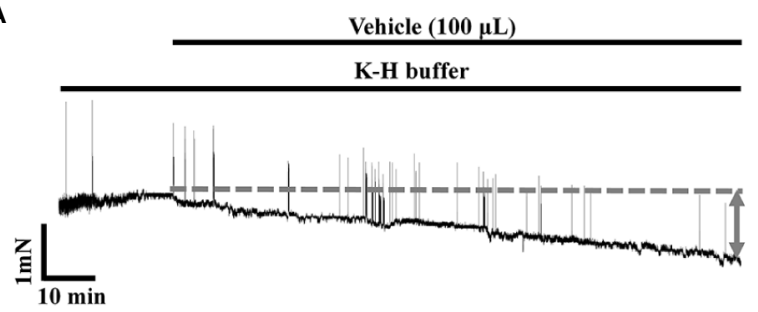

B

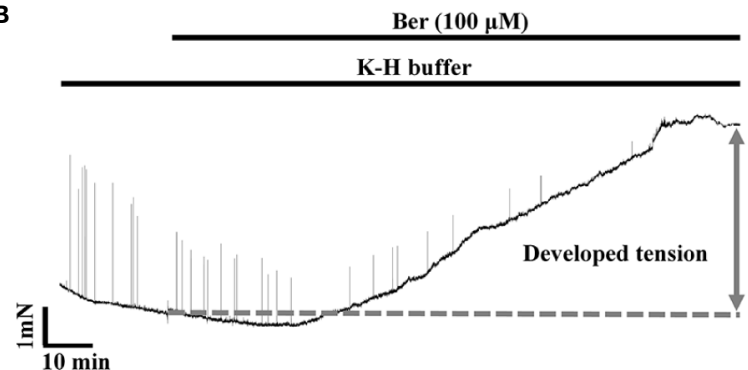

C

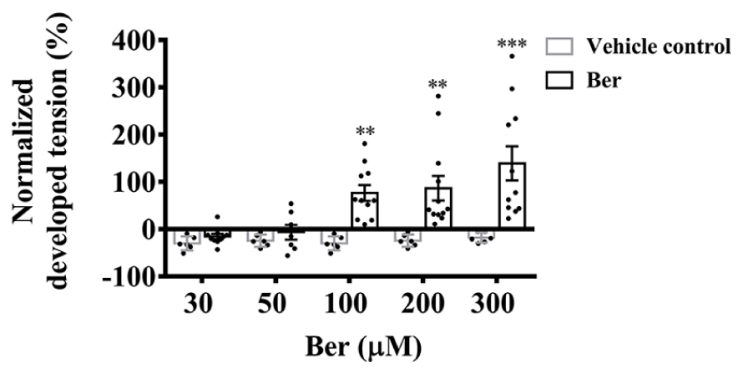

FIGURE 2 | Berberine increased the tension of freshly isolated left ventricular muscle (LVM) strips. (A, B) Original isometric tension recordings showing that berberine $(100 \mu \mathrm{M})$ increased the tension of LVM strips. (C) Summary data showing that berberine increased the tension of LVM strips in a concentration-dependent manner. The numbers of repeats are as follows: 30 $\mu \mathrm{M}$ Ber, $\mathrm{n}=10, \mathrm{~N}=10 ; 50 \mu \mathrm{M}$ Ber, $\mathrm{n}=7, \mathrm{~N}=7 ; 100 \mu \mathrm{M}$ and $300 \mu \mathrm{M}$ Ber, $n=11, N=11 ; 200 \mu M$ Ber, $n=12, N=12 ; n$ and $N$ are the numbers of LVM strips and rats, respectively. Ber stands for berberine. ${ }^{* *} p<0.01$, ${ }^{* * *} p<$ 0.001 vs. vehicle control group; two-way ANOVA with Sidak's multiple comparisons test.

manner (Figures 3B, C). Berberine $(100 \mu \mathrm{M})$ increased the tension by $77.9 \pm 14.4 \%$, while it decreased by $23.1 \pm 2.8 \%$ with time in the absence of berberine (Figure 3). These indicated that berberine could enhance the contractile force and eliminate the epinephrine-evoked phasic contractions in the LVM.

The action potentials generated by the sinoatrial node transmit through the cardiac electrical conduction system to cause myocardial contraction (Nakao et al., 2015). The electrical field stimulations (EFS) induced phasic contractions in LVM strips, but it did not prevent the decline in the tension of LVM strips with time (Figure $\mathbf{4 A}$ ). The addition of berberine prevented the tension decrease and further increased the tension of EFS-paced LVM strips (Figure $4 \mathbf{B}$ ). The tension increased by $42.5 \pm 21.0 \%$ following the addition of $100 \mu \mathrm{M}$ berberine, but it decreased by $39.7 \pm 5.5 \%$ with time in the

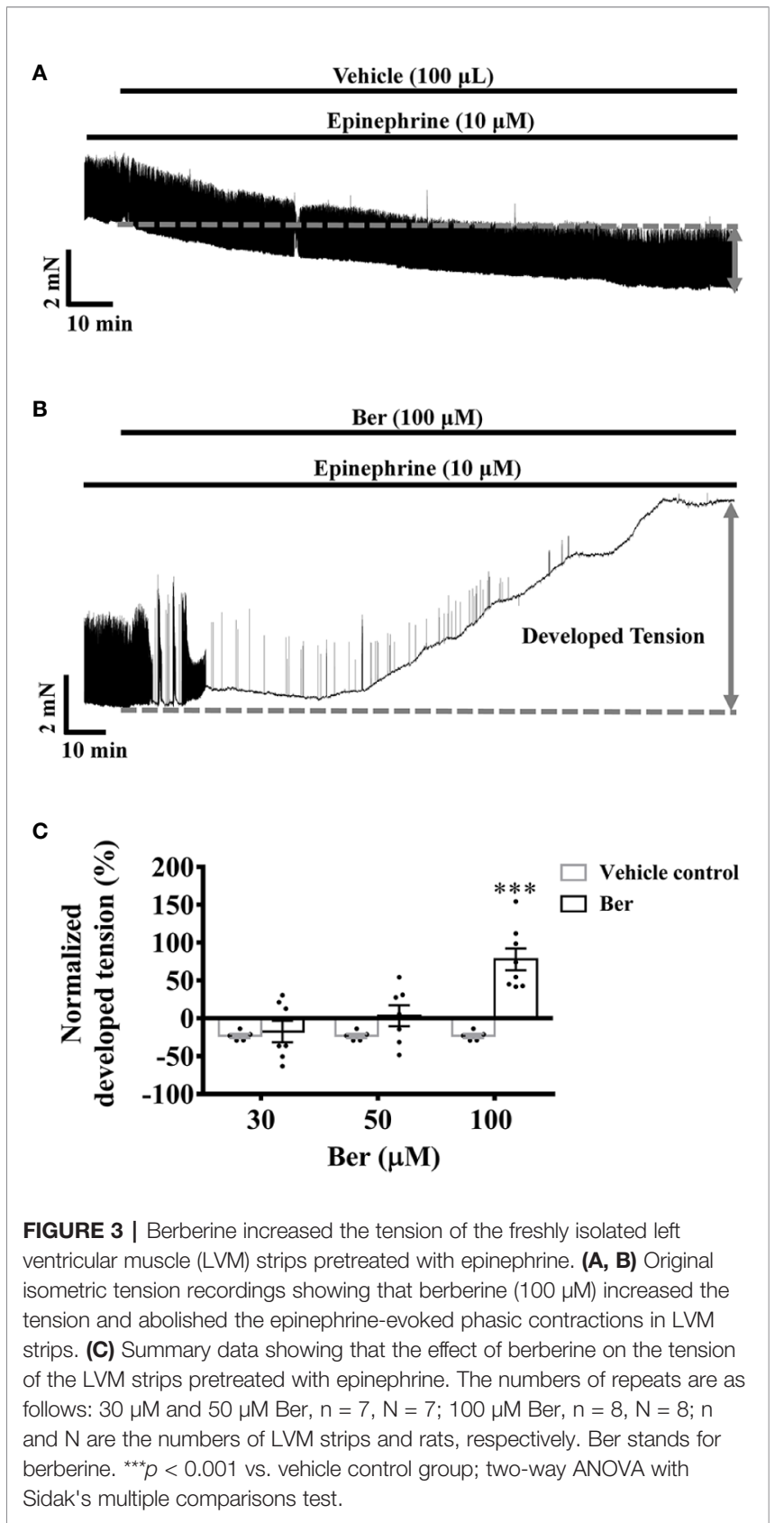

absence of berberine (Figure 4). These data suggested that berberine could improve heart function by increasing the isometric tension of the ventricular muscle. The cardiac contractility relies on the intracellular $\mathrm{Ca}^{2+}$ level of the cardiomyocytes, so we next determined the effect of berberine on the intracellular $\mathrm{Ca}^{2+}$ level of $\mathrm{LV}$ myocytes.

\section{Berberine Increased the Intracellular $\mathrm{Ca}^{2+}$ Level of LV Myocytes in a Concentration- Dependent Manner}

The increase of the intracellular $\mathrm{Ca}^{2+}$ level is the key to cardiac contractions (Bers, 2002; Eisner et al., 2017). In the range of 30$300 \mu \mathrm{M}$, berberine increased the intracellular $\mathrm{Ca}^{2+}$ level of freshly 
A

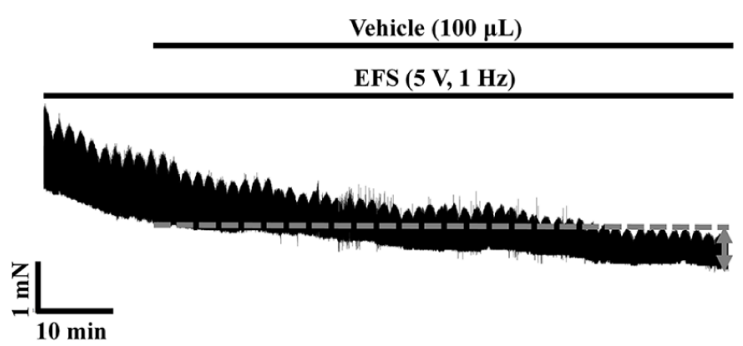

B

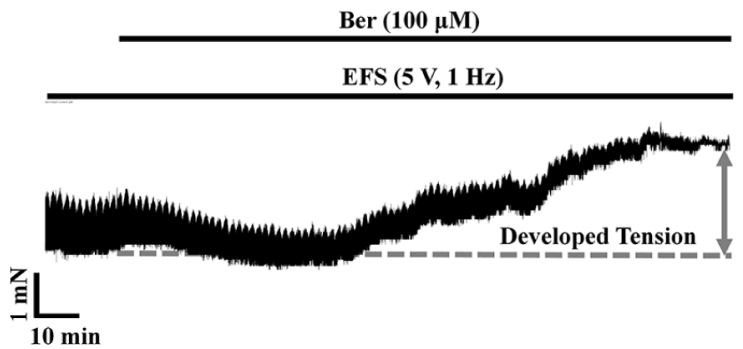

C

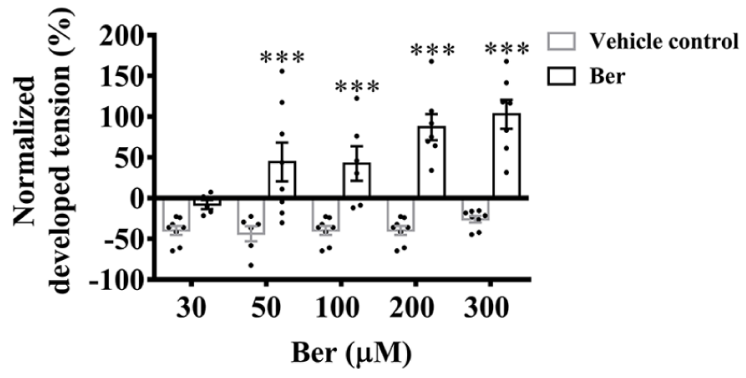

FIGURE 4 | Berberine increased the tension of the electrical field stimulation (EFS)-paced left ventricular muscle (LVM) strips. (A, B) Original isometric tension recordings showing that berberine $(100 \mu \mathrm{M})$ increased the tension of the EFS-paced LVM strips (5 V, $1 \mathrm{~Hz}$ ). (C) Summary data indicating that berberine increases the tension of the EFS-paced LVM strips in a concentration-dependent manner. The numbers of repeats are as follows: 30 $\mu \mathrm{M}$ Ber, $\mathrm{n}=5, \mathrm{~N}=5$; $50 \mu \mathrm{M}$ Ber, $\mathrm{n}=8, \mathrm{~N}=8$; $100 \mu \mathrm{M}$ Ber, $\mathrm{n}=6, \mathrm{~N}=6$; $200 \mu \mathrm{M}$ Ber and $300 \mu \mathrm{M}$ Ber, $\mathrm{n}=7, \mathrm{~N}=7 ; \mathrm{n}$ and $\mathrm{N}$ are the numbers of LVM strips and rats, respectively. Ber stands for berberine. ${ }^{* *} p<0.001$ vs. vehicle control group; two-way ANOVA with Sidak's multiple comparisons test.

isolated LV myocytes (Figure 5C). The fluorescence intensity of Fluo4- $\mathrm{Ca}^{2+}$ increased to $120.8 \pm 21.1 \%$ with the treatment of 100 $\mu \mathrm{M}$ berberine, while it decayed with time to $88.83 \pm 10.71 \%$ in the absence of berberine (Figure 5). These results indicated the berberine might elicit the positive inotropic effect by elevating the intracellular $\mathrm{Ca}^{2+}$ level of LV myocytes.

\section{The Berberine-Induced Tension Increase in LVM Strips Was Extracellular $\mathrm{Ca}^{2+}$-dependent}

Extracellular $\mathrm{Ca}^{2+}$ influx contributes to the increase in the intracellular $\mathrm{Ca}^{2+}$ level of LV myocytes, which induces cardiac contraction (Bers, 2002; Eisner et al., 2017; Gilbert et al., 2020). To investigate the role of $\mathrm{Ca}^{2+}$ influx in the berberine-induced
A

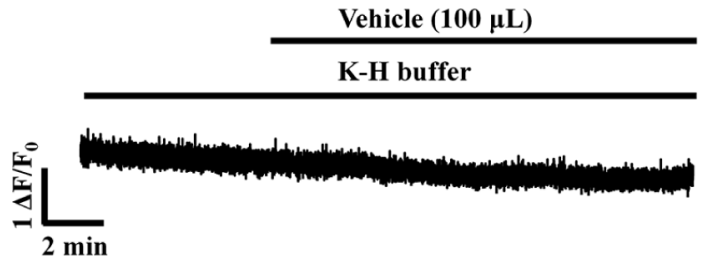

B

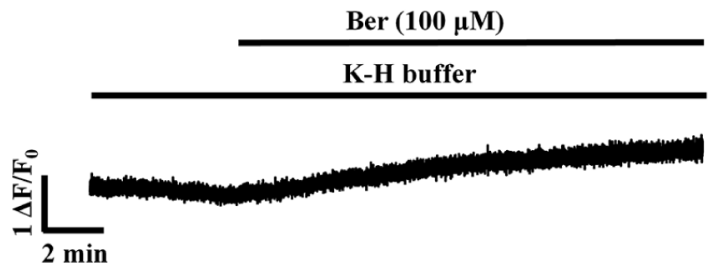

C

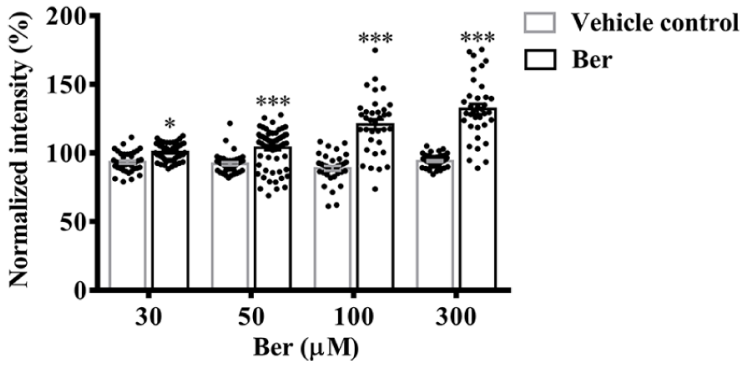

FIGURE 5 | Berberine concentration-dependently increased the intracellular $\mathrm{Ca}^{2+}$ level of freshly isolated left ventricular (LV) myocytes. (A, B) Original $\mathrm{Ca}^{2+}$ imaging recordings showing that berberine $(100 \mu \mathrm{M})$ increased the intracellular $\mathrm{Ca}^{2+}$ level of freshly isolated LV myocytes. (C) Summary data showing that berberine concentration-dependently increased the intracellular $\mathrm{Ca}^{2+}$ level. The numbers of repeats are as follows: $30 \mu \mathrm{M}$ Ber, $n=54, \mathrm{~N}=3$; $50 \mu \mathrm{M}$ Ber, $\mathrm{n}=65, \mathrm{~N}=3 ; 100 \mu \mathrm{M}$ Ber, $\mathrm{n}=35, \mathrm{~N}=3 ; 300 \mu \mathrm{M}$ Ber, $\mathrm{n}=36$, $\mathrm{N}=3$; $\mathrm{n}$ and $\mathrm{N}$ are the numbers of LV myocytes and rats, respectively. Ber stands for berberine. ${ }^{*} p<0.05,{ }^{* * *} p<0.001$ vs. vehicle control group; twoway ANOVA with Sidak's multiple comparisons test.

tension increase in LVM strips, we carried out experiments under the $\mathrm{Ca}^{2+}$-free condition (Song et al., 2014). The removal of extracellular $\mathrm{Ca}^{2+}$ significantly attenuated the berberineinduced tension increase in LVM strips (Figure 6E). In the absence of extracellular $\mathrm{Ca}^{2+}$, the tension increased by $17.7 \pm$ $19.8 \%$ following the addition of berberine $(300 \mu \mathrm{M})$ (Figures 6 C, D), while it increased by $121.0 \pm 18.3 \%$ in the presence of extracellular $\mathrm{Ca}^{2+}(1.5 \mathrm{mM})$ (Figures $\left.6 \mathbf{A}, \mathbf{B}\right)$. It suggested that the berberine-induced tension increase in LVM strips is extracellular $\mathrm{Ca}^{2+}$-dependent.

\section{Nifedipine Attenuated the Berberine- Induced Tension Increase in LVM Strips}

LTCCs are the major $\mathrm{Ca}^{2+}$ channels that allow extracellular $\mathrm{Ca}^{2+}$ influx in LV myocytes (Jaleel et al., 2008). The selective LTCC inhibitor nifedipine $(10 \mu \mathrm{M})$ can greatly block the channels 
A

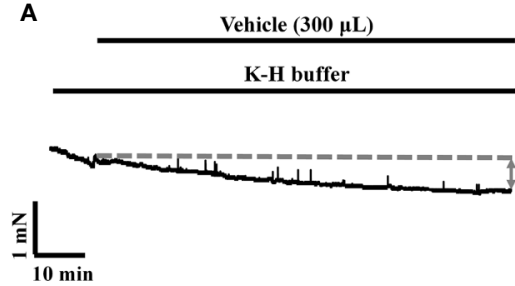

C

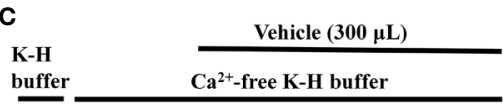

buffer $\mathrm{Ca}^{2+}$-free $\mathrm{K}-\mathrm{H}$ buffer

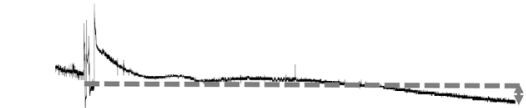

$\stackrel{\text { z】 }}{10 \mathrm{~min}}$

E

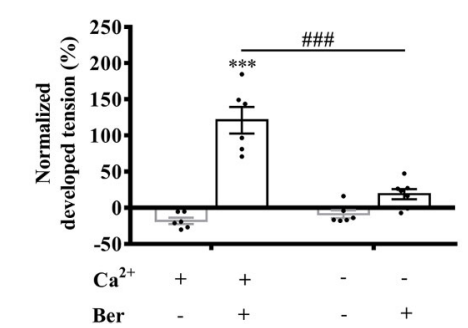

B

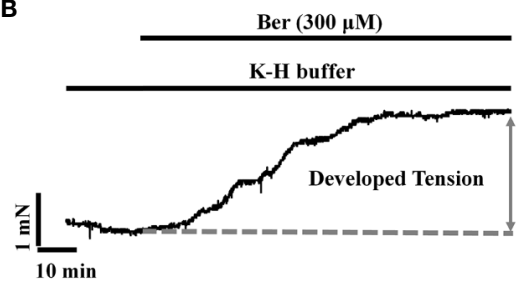

D

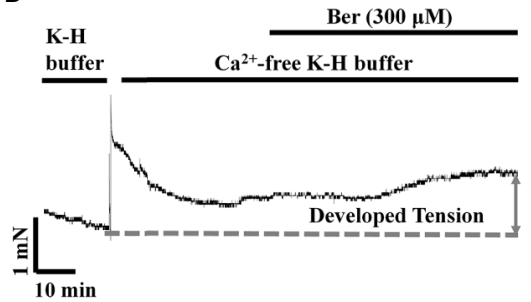

FIGURE 6 | The removal of extracellular $\mathrm{Ca}^{2+}$ hindered the berberine-induced tension increase in left ventricular muscle (LVM) strips. (A-D) Original isometric tension recordings of the LVM strips treated with vehicle (A), $300 \mu \mathrm{M}$ Ber (B); vehicle (C) and $300 \mu \mathrm{M}$ Ber (D) under the Ca ${ }^{2+}$-free condition, respectively.

(E) Summary data showing that the removal of extracellular $\mathrm{Ca}^{2+}$ significantly reduced the ability of berberine to increase the tension of LVM strips. The numbers of repeats are as follows: vehicle control of $300 \mu \mathrm{M}$ Ber, $n=6, N=6 ; 300 \mu \mathrm{M}$ Ber, $n=6, N=6$; vehicle control of $300 \mu \mathrm{M}$ Ber in the Ca ${ }^{2+}$-free Krebs-Hensseleit (K-H) buffer, $\mathrm{n}=6, \mathrm{~N}=6 ; 300 \mu \mathrm{M}$ Ber in the $\mathrm{Ca}^{2+}$-free $\mathrm{K}-\mathrm{H}$ buffer, $\mathrm{n}=7, \mathrm{~N}=7 ; \mathrm{n}$ and $\mathrm{N}$ are the numbers of LVM strips and rats, respectively. Ber stands for berberine.

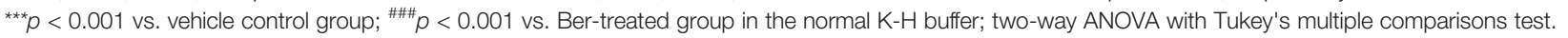

(Carre et al., 2014). Berberine $(300 \mu \mathrm{M})$ increased the tension in LVM strips by $121.0 \pm 18.3 \%$ and $63.6 \pm 7.5 \%$ in the absence and presence of nifedipine $(10 \mu \mathrm{M})$, respectively $(p<0.05$, Figures $7 \mathrm{~B}, \mathrm{D}, \mathrm{E})$.

\section{Berberine Induced an Additional Increase in the Tension of LVM Strips in the Presence of LTCC Opener FPL-64716}

The LTCC opener FPL-64716 enhances $\mathrm{Ca}^{2+}$ influx (Kang et al., 2012). FPL-64716 $(10 \mu \mathrm{M})$ increased the tension of LVM strips by $105.1 \pm 70.8 \%$, and the subsequent addition of berberine induced a further increase by a total of $232.9 \pm 56.9 \%$ (Figure 8B). It increased by $41.3 \pm 29.9 \%$ in the vehicle control group (Figure 8A). These results indicated that the positive inotropic effects of berberine were LTCC-independent. To directly investigate the effect of berberine on the $\mathrm{Ca}^{2+}$ influx, we next carried out experiments with isolated LV myocytes under the $\mathrm{Ca}^{2+}$-free condition or in the presence of the LTCC blocker nifedipine.

\section{Berberine Increased the Intracellular $\mathrm{Ca}^{2+}$ Level of LV Myocytes Dependent on the Extracellular $\mathrm{Ca}^{2+}$}

Berberine $(300 \mu \mathrm{M})$ increased the fluorescence intensity of Fluo4$\mathrm{Ca}^{2+}$ of the isolated $\mathrm{LV}$ myocytes to $130.0 \pm 2.5 \%$ in the extracellular buffer containing $1.5 \mathrm{mM} \mathrm{Ca}^{2+}$ (Figures 9A, B). The removal of extracellular $\mathrm{Ca}^{2+}$ significantly attenuated the berberine-induced fluorescence increase to $106.7 \pm 3.3 \%$ (Figures 9C-E). These results indicated that the berberine-induced intracellular $\mathrm{Ca}^{2+}$ elevation was extracellular $\mathrm{Ca}^{2+}$-dependent and that berberine might enhance the $\mathrm{Ca}^{2+}$ influx.

Next, we investigated the role of LTCCs in the berberineinduced increase in the intracellular $\mathrm{Ca}^{2+}$ level. In the presence of nifedipine, berberine increased the fluorescence intensity of Fluo4$\mathrm{Ca}^{2+}$ to $130.7 \pm 3.2 \%$ of the basal level in LV myocytes. It rose to $130.0 \pm 2.5 \%$ in the absence of nifedipine (Figures 10B, D). These suggested that berberine increases the intracellular $\mathrm{Ca}^{2+}$ concentration also by enhancing the $\mathrm{Ca}^{2+}$ entry via an LTCC- 
A

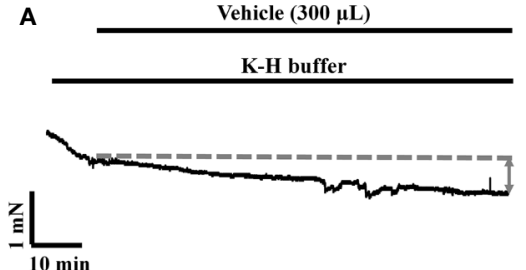

C
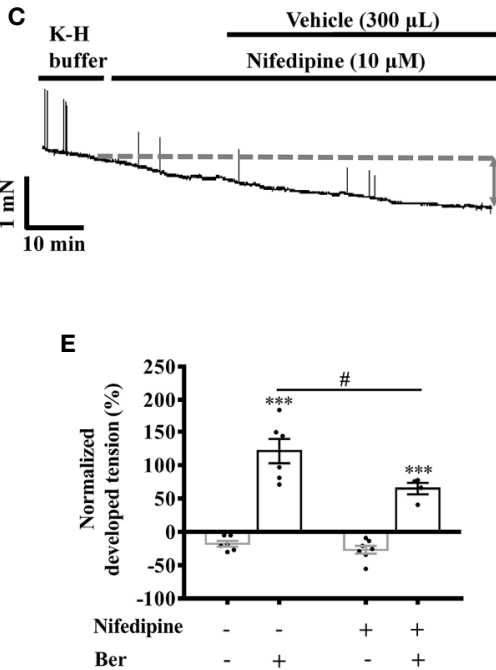

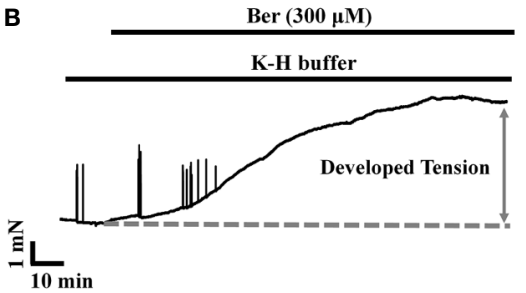

D

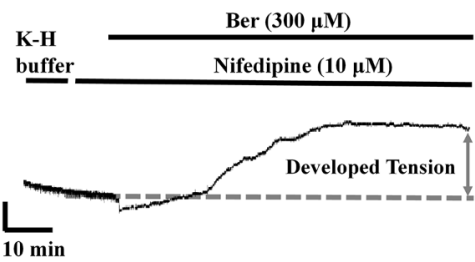

FIGURE 7 | Nifedipine attenuated the berberine-induced tension increase in left ventricular muscle (LVM) strips. (A-D) Original isometric tension recordings of the LVM strips treated with vehicle (A), $300 \mu \mathrm{M}$ Ber (B), $10 \mu \mathrm{M}$ nifedipine (C), and $300 \mu \mathrm{M}$ Ber in the presence of $10 \mu \mathrm{M}$ nifedipine (D), respectively. (E) Summary data showing nifedipine hindered the $300 \mu \mathrm{M}$ berberine-induced tension increase in LVM strips. The numbers of repeats are as follows: vehicle control of $300 \mu \mathrm{M}$ Ber, $\mathrm{n}=$ 6, $N=6 ; 300 \mu M$ Ber, $n=6, N=6 ; 10 \mu M$ nifedipine, $n=7, N=7 ; 300 \mu M$ Ber plus $10 \mu M$ nifedipine, $n=5, N=5 ; n$ and $N$ are the numbers of $L V M$ strips and rats, respectively. Ber stands for berberine. ${ }^{* *} p<0.001$ vs. vehicle control group; ${ }^{*} p<0.05$, vs. $300 \mu \mathrm{M}$ Ber-treated group; two-way ANOVA with Tukey's multiple comparisons test.

independent pathway. The $\mathrm{Na}^{+}$is also critical for regulating the excitation-contraction coupling. Next, we determined the role of the extracellular $\mathrm{Na}^{+}$in the berberine-induced tension increase in the LVM strips.

\section{Berberine Increased the Tension in LVM Strips Dependent on the Extracellular $\mathrm{Na}^{+}$}

To determine the role of extracellular $\mathrm{Na}^{+}$in the berberineinduced tension increase in LVM strips, $\mathrm{Cs}^{+}$, and NMDG were used to replace extracellular $\mathrm{Na}^{+}$, respectively (Xin et al., 2005). The lowering of extracellular $\mathrm{Na}^{+}$caused a transient increase in the tension of LVM strips (Figures 11B, D). The subsequent addition of berberine induced a smaller increase in the tension of LVM strips in the $\mathrm{Na}^{+}$-free $\mathrm{K}-\mathrm{H}$ buffer than that in the standard $\mathrm{K}-\mathrm{H}$ buffer containing $144 \mathrm{mM} \mathrm{NaCl}$. The berberine-induced tension increased with the concentration of $\mathrm{Na}^{+}$rising in the buffer (Figures 11C, E). These data indicated that the extracellular $\mathrm{Na}^{+}$ is essential for the tension increase in LVM strips caused by berberine.

\section{The Berberine-Induced Increase in the Intracellular $\mathrm{Ca}^{2+}$ Level of LV Myocytes Was Extracellular $\mathrm{Na}^{+}$-Dependent}

To further investigate the role of extracellular $\mathrm{Na}^{+}$in the berberine-induced tension increase in LVM strips, we examined the impact of extracellular $\mathrm{Na}^{+}$on the berberineinduced rise in the intracellular $\mathrm{Ca}^{2+}$ level of LV myocytes. Berberine $(300 \mu \mathrm{M})$ raised the fluorescence intensity of Fluo4$\mathrm{Ca}^{2+}$ to $132.5 \pm 18.1 \%$ of the basal level in myocytes perfused with the modified $\mathrm{K}-\mathrm{H}$ buffer containing $125 \mathrm{mM} \mathrm{NaCl}$ (Figure 12B). We perfused the myocytes with a modified K$\mathrm{H}$ buffer containing $62.5 \mathrm{mM} \mathrm{NaCl}$ and $62.5 \mathrm{mM}$ NMDG. It caused a transient increase in the fluorescence intensity of Fluo4- $\mathrm{Ca}^{2+}$. Following a 30-min equilibration, the subsequent addition of berberine $(300 \mu \mathrm{M})$ elevated the fluorescence intensity of Fluo4- $\mathrm{Ca}^{2+}$ to $116.2 \pm 22.5 \%$ of the basal level (Figure 12D). The berberine-induced increase in the fluorescence intensity in LV myocytes was significantly less in the $62.5 \mathrm{mM}-\mathrm{NaCl} \mathrm{K}-\mathrm{H}$ buffer than that in the standard, 


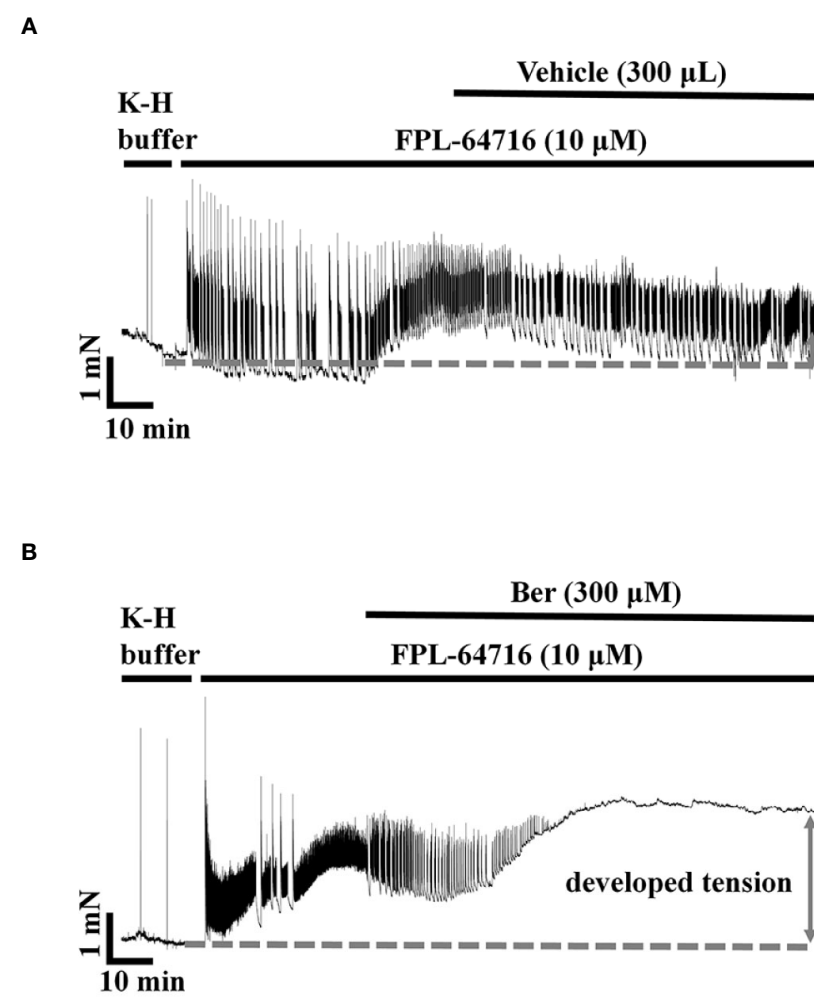

C

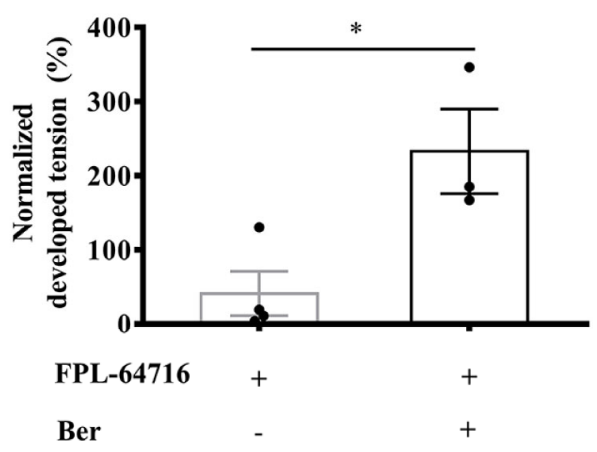

FIGURE 8 | Berberine increased the tension of the freshly isolated left ventricular muscle (LVM) strips pretreated with FPL-64716. (A, B) Original isometric tension recordings of the LVM strips treated with $10 \mu \mathrm{M}$ FPL-64716 (A) and $300 \mu \mathrm{M}$ berberine in the presence of $10 \mu \mathrm{M}$ FPL-64716 (B). (C) Summary data showing berberine induced an additional increase in the tension of the LVM strips pretreated with FPL-64716. The numbers of repeats are as follows: $10 \mu \mathrm{M}$ FPL-64716, $\mathrm{n}=4, \mathrm{~N}=3 ; 300 \mu \mathrm{M}$ Ber plus $10 \mu \mathrm{M}$ FPL-64716, $n=3, N=3 ; n$ and $N$ are the numbers of LVM strips and rats, respectively. Ber stands for berberine. * $p<0.05$ vs. $10 \mu \mathrm{M}$ FPL-64716treated group; two-tailed unpaired Student's t-test.

modified $\mathrm{K}-\mathrm{H}$ buffer containing $125 \mathrm{mM} \mathrm{NaCl}$ (Figure 12E). These data indicated that the elevation in the intracellular $\mathrm{Ca}^{2+}$ level by berberine was extracellular $\mathrm{Na}^{+}$-dependent.

\section{DISCUSSION}

Here we reported that berberine significantly increased the LVDP, $+d p / d t_{\max }$, and the $|-d p / d t|_{\max }$ in Langendorff-perfused isolated rat hearts. Berberine increased the tension of the isolated LVM strips and the intracellular $\mathrm{Ca}^{2+}$ level of isolated $\mathrm{LV}$ myocytes. The removal of extracellular $\mathrm{Ca}^{2+}$ or lowering extracellular $\mathrm{Na}^{+}$ reduced the berberine-induced increases in both LVM tension and the $\mathrm{Ca}^{2+}$ levels in LV myocytes. These results suggested that berberine increased the intracellular $\mathrm{Ca}^{2+}$ concentration of $\mathrm{LV}$ myocytes dependent on the extracellular $\mathrm{Ca}^{2+}$ and $\mathrm{Na}^{+}$. It consequently exerted its positive inotropic effect on the rat heart.

A clinical study showed that oral administration of berberine $(1.2-2.0 \mathrm{~g} / \mathrm{d})$ increased LV ejection fraction in patients with chronic congestive heart failure who also took medications of angiotensin-converting enzyme inhibitors, digoxin, diuretics, and nitrates (Zeng et al., 2003). The LV ejection fraction increase in patients with plasma berberine concentrations higher than $0.1 \mathrm{mg} / \mathrm{L}(\sim 0.3 \mu \mathrm{M})$ was more significant than in those with concentrations lower than $0.1 \mathrm{mg} / \mathrm{L}$ (Zeng et al., 2003). In the concentration range from 10 to $20 \mu \mathrm{M}$, berberine exhibited positive inotropic effects on the isolated rat hearts (Figures 1B-D). The sufficient concentrations in the in vitro study were higher than those observed in the clinical studies (Zeng and Zeng, 1999; Zeng et al., 2003).

Besides, Tan investigated the tissue distribution of berberine and its metabolites in rats with a single oral dose of $200 \mathrm{mg} / \mathrm{kg}$ (Tan et al., 2013). The time for berberine to reach its maximal concentrations in the plasma $(\sim 76.8 \mathrm{nM})$ and heart $(\sim 2 \mathrm{ng} / \mathrm{g})$ were $1.33 \pm 0.29$ and $24 \mathrm{~h}$, respectively. Berberrubine, one of the primary active metabolites of berberine, was also found in the heart (Li et al., 2011; Tan et al., 2013). The metabolite of berberine might contribute to the therapeutic effects of berberine as well. The significant decrease in resting systolic and diastolic blood pressures might also be beneficial to the heart failure patients treated with berberine (Zeng et al., 2003).

Berberine increased both the tension of LVM strips and the intracellular $\mathrm{Ca}^{2+}$ level of $\mathrm{LV}$ myocytes in the concentration range from 30 or 50 to $300 \mu \mathrm{M}$ (Figures 2 and 5). The effective concentrations of berberine in these two preparations were higher than those $(10-20 \mu \mathrm{M})$ in the Langendorff-perfused whole hearts. A previous study also showed that berberine $(10-300 \mu \mathrm{M})$ increased the developed force in the left atrium of guinea pigs (Shaffer, 1985). These suggested that the impact of berberine on the cardiac function in patients was a systemic phenomenon rather than only via targeting the myocytes. Berberine increased the intracellular $\mathrm{Ca}^{2+}$ level of LV myocytes in a concentration-dependent manner, which reached the maximal level at $300 \mu \mathrm{M}$ (Figure 5). This response was consistent with the maximal tension increase induced by $300 \mu \mathrm{M}$ berberine in LVM strips (Figures 2 and 5). Therefore, we selected $300 \mu \mathrm{M}$ berberine in the final study to determine the underlying mechanism.

The intracellular $\mathrm{Ca}^{2+}$ concentration in LV myocytes is the key for controlling the cardiac contractions, and the $\mathrm{Ca}^{2+}$ influx is critical for raising the intracellular $\mathrm{Ca}^{2+}$ level (Bers, 2002; Eisner et al., 2017; Gilbert et al., 2020). Berberine elevated the tension of 


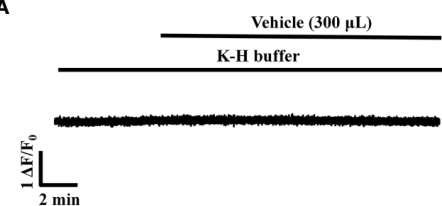

C

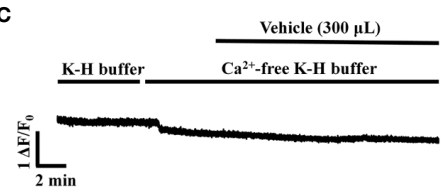

E

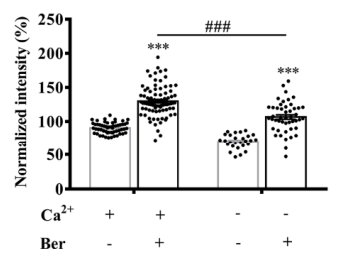

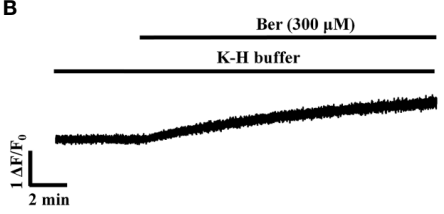

D

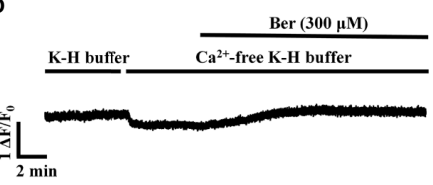

FIGURE 9 | The removal of extracellular $\mathrm{Ca}^{2+}$ hindered the berberine-induced increase in the intracellular Ca ${ }^{2+}$ level of freshly isolated LV myocytes. (A-D) Original $\mathrm{Ca}^{2+}$ imaging recordings of the LV myocytes treated with vehicle (A) and $300 \mu \mathrm{M}$ berberine (B); vehicle (C) and $300 \mu \mathrm{M}$ berberine (D) in the Ca ${ }^{2+}$-free modified Krebs-Hensseleit $(\mathrm{K}-\mathrm{H})$ buffer, respectively. (E) Summary data showing that the removal of extracellular $\mathrm{Ca}^{2+}$ significantly hindered the $300 \mu \mathrm{M}$ berberine-induced increase in the intracellular $\mathrm{Ca}^{2+}$ level of LV myocytes. The numbers of repeats are as follows: vehicle control of $300 \mu \mathrm{M}$ Ber, $\mathrm{n}=57, \mathrm{~N}=3 ; 300 \mu \mathrm{M}$ Ber, $\mathrm{n}=83, \mathrm{~N}=$ 3; vehicle control of $300 \mu \mathrm{M}$ Ber in the $\mathrm{Ca}^{2+}$-free modified $\mathrm{K}-\mathrm{H}$ buffer, $\mathrm{n}=27, \mathrm{~N}=3 ; 300 \mu \mathrm{M}$ Ber in the Ca ${ }^{2+}$-free modified $\mathrm{K}-\mathrm{H}$ buffer, $\mathrm{n}=47, \mathrm{~N}=3$; $\mathrm{n}$ and $\mathrm{N}$ are the numbers of LV myocytes and rats, respectively. Ber stands for berberine. ${ }^{* * *} p<0.001$ vs. vehicle control group; ${ }^{\# \# \#} p<0.001$ vs. Ber-treated group in the normal modified K-H buffer; two-way ANOVA with Tukey's multiple comparisons test.

A

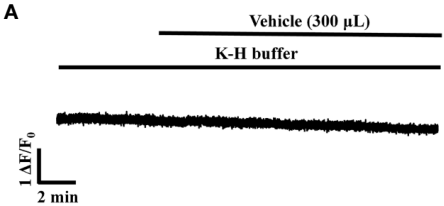

C

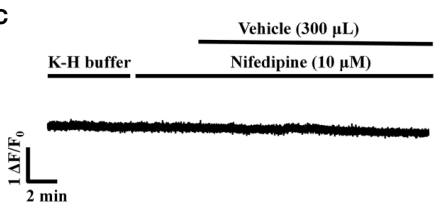

E

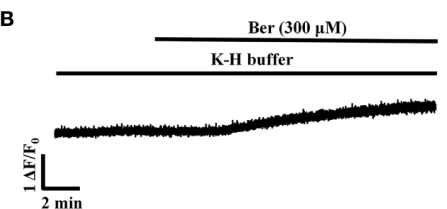

D

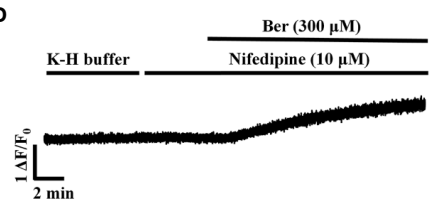

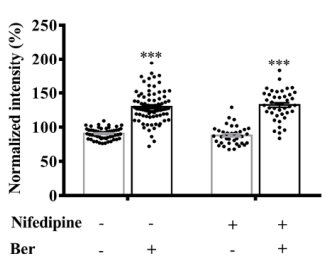

FIGURE 10 | Nifedipine did not influence the $300 \mu \mathrm{M}$ berberine-induced increase in the intracellular $\mathrm{Ca}^{2+}$ level of freshly isolated left ventricular (LV) myocytes. (A-D) Original $\mathrm{Ca}^{2+}$ imaging recordings of the LV myocytes treated with vehicle (A), $300 \mu \mathrm{M}$ Ber (B), $10 \mu \mathrm{M}$ nifedipine (C) and $300 \mu \mathrm{M}$ Ber in the presence of $10 \mu \mathrm{M}$ nifedipine (D). (E) Summary data showing nifedipine did not affect the $300 \mu \mathrm{M}$ berberine-induced increase in the intracellular Ca ${ }^{2+}$ level of LV myocytes. The numbers of repeats are as follows: vehicle control of $300 \mu \mathrm{M}$ Ber, $n=57, N=4 ; 300 \mu \mathrm{M}$ Ber, $n=83, N=4 ; 10 \mu \mathrm{M}$ nifedipine, $n=37, \mathrm{~N}=4 ; 300 \mu \mathrm{M}$ Ber plus $10 \mu \mathrm{M}$ nifedipine, $n=46, N=4 ; n$ and $N$ are the numbers of LV myocytes and rats, respectively. Ber stands for berberine. ${ }^{\star * *} p<0.001$ vs. vehicle control group; two-way ANOVA with Tukey's multiple comparisons test. 


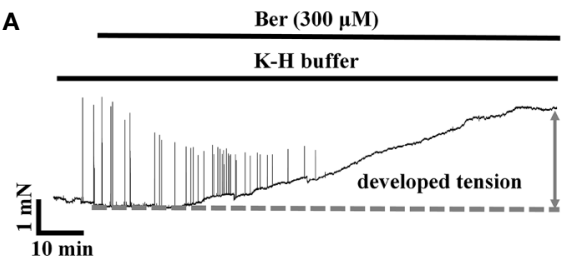

B
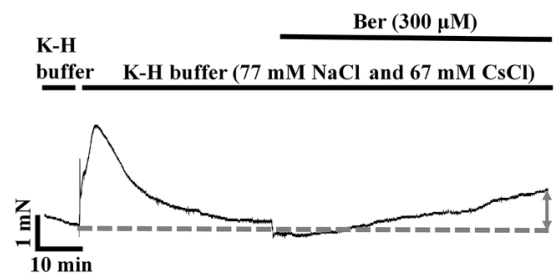

D

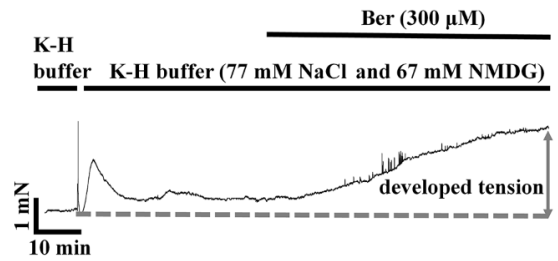

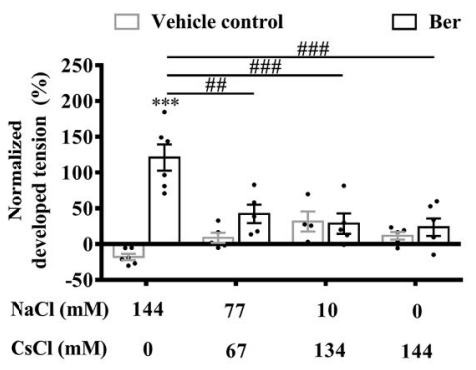

E

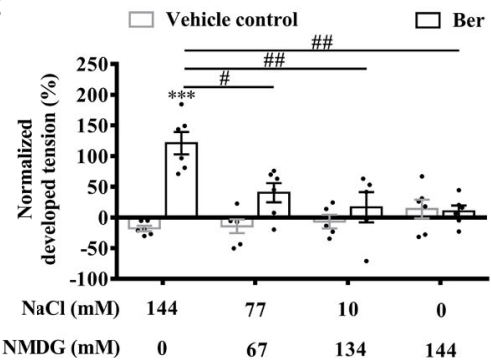

FIGURE 11 | The berberine-induced tension increase in left ventricular muscle (LVM) strips was extracellular $\mathrm{Na}^{+}$-dependent. (A, B, D) Original isometric tension recordings of the LVM strips treated with $300 \mu \mathrm{M}$ berberine (A), and $300 \mu \mathrm{M}$ berberine under the low $\mathrm{Na}^{+}$condition where $\mathrm{NaCl}$ of the $\mathrm{Krebs}-\mathrm{Hensseleit}(\mathrm{K}-\mathrm{H})$ buffer was replaced with $\mathrm{CsCl}(\mathbf{B})$ or with NMDG (D). (C, E) Summary data indicating that the $300 \mu \mathrm{M}$ berberine-induced tension increase has a positive correlation with the concentrations of extracellular $\mathrm{NaCl}$. The numbers of repeats are as follows: experiments with the normal $\mathrm{K}-\mathrm{H}$ buffer, $300 \mathrm{MM}$ Ber, $\mathrm{n}=6, \mathrm{~N}=6$. Experiments with the $\mathrm{K}-\mathrm{H}$ buffer in which $\mathrm{NaCl}$ was replaced with $\mathrm{CsCl}$ : $300 \mu \mathrm{M}$ Ber in the buffer containing 77 or $10 \mathrm{mM} \mathrm{NaCl,} \mathrm{n}=5, \mathrm{~N}=5$; $300 \mu \mathrm{M}$ Ber in the buffer containing 0 $\mathrm{mM} \mathrm{NaCl}, \mathrm{n}=6, \mathrm{~N}=6$. Experiments with the $\mathrm{K}-\mathrm{H}$ buffer in which $\mathrm{NaCl}$ was replaced with NMDG: $300 \mu \mathrm{M}$ Ber in the buffer containing 77 or $0 \mathrm{mM}$ NaCl, $\mathrm{n}=6, \mathrm{~N}=$ 6; $300 \mu \mathrm{M}$ Ber in the buffer containing $10 \mathrm{mM} \mathrm{NaCl}, \mathrm{n}=5, \mathrm{~N}=5 . \mathrm{n}$ and $\mathrm{N}$ are the numbers of LVM strips and rats, respectively. Ber stands for berberine. ${ }^{* \star *} p<$

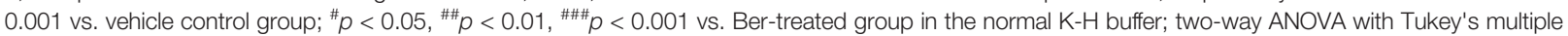
comparisons test.

LVM strips and the intracellular $\mathrm{Ca}^{2+}$ concentration in the isolated LV myocytes bathed in a buffer containing $1.5 \mathrm{mM} \mathrm{Ca}^{2+}$ (Figures 6B and 9B). The removal of $\mathrm{Ca}^{2+}$ from the buffer attenuated the functions of berberine (Figures 6D and 9D). These suggested that the berberine-induced tension increase in LVM strips is dependent on the extracellular $\mathrm{Ca}^{2+}$, and berberine elevates the intracellular $\mathrm{Ca}^{2+}$ level in LV myocytes by enhancing the $\mathrm{Ca}^{2+}$ influx.

L-type $\mathrm{Ca}^{2+}$ channel (LTCC) is the primary channel for $\mathrm{Ca}^{2+}$ entry in cardiac myocytes. Previous studies showed that berberine decreased or increased LTCC currents in guinea pig ventricular cells (Wang and Zheng, 1997; Xu et al., 1997), but had no effect on the LTCC current in cat ventricular cells (Sanchez-Chapula, 1996). Our results showed that the pretreatment with nifedipine did not affect the berberineinduced increase in the intracellular $\mathrm{Ca}^{2+}$ level of rat $\mathrm{LV}$ myocytes (Figure 10). This result indicated that berberine enhanced the $\mathrm{Ca}^{2+}$ entry through pathways not dependent on LTCCs.

The LTCC inhibitor nifedipine significantly attenuated the berberine-induced tension increase in the rat LVM strips (Figure 7). In the presence of the LTCC opener FPL-64716, berberine caused an additional increase in LVM strip tension (Figure 8). Besides, berberine significantly increased the intracellular $\mathrm{Ca}^{2+}$ concentration of LV myocytes bathed in the $\mathrm{Ca}^{2+}$-free buffer (Figure 9D). It indicated the berberine could enhance the $\mathrm{Ca}^{2+}$ release from the intracellular stores, but further research is needed to determine the mechanism. These suggested that berberine might also exert a positive inotropic effect through an LTCC-independent mechanism.

Sodium is also a critical cation regulating the excitationcontraction coupling in cardiomyocytes. The positive inotropic effect of berberine on LV strips bathed in the low $\mathrm{Na}^{+}$buffer decreased (Figure 11). This phenomenon demonstrated that the 
A

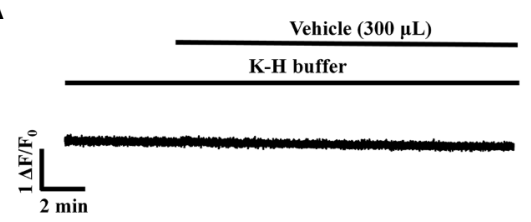

C K-H buffer K-H buffer (62.5 $\mathrm{mM} \mathrm{NaCl)}$

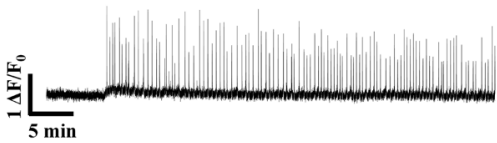

B

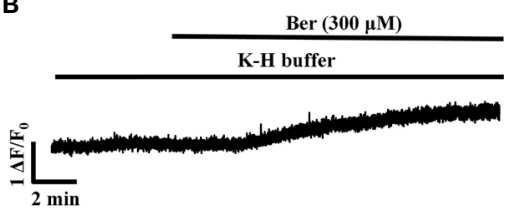

D

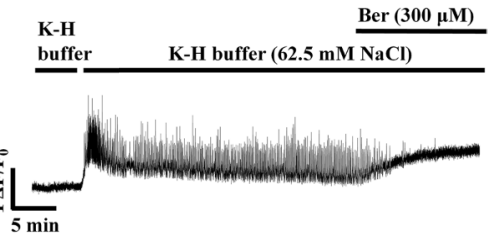

E

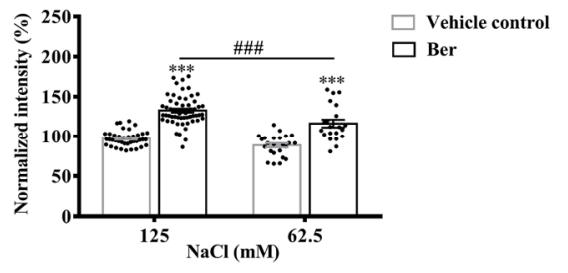

FIGURE 12 | The berberine-induced increase in the intracellular $\mathrm{Ca}^{2+}$ level of left ventricular (LV) myocytes was extracellular $\mathrm{Na}^{+}$-dependent. (A-D) Original Ca ${ }^{2+}$ imaging recordings of the LV myocytes treated with vehicle (A) and $300 \mu \mathrm{M}$ Ber (B); vehicle (C) and $300 \mu \mathrm{M}$ Ber (D) in the modified Krebs-Hensseleit (K-H) buffer containing $62.5 \mathrm{mM} \mathrm{NaCl}$ and $62.5 \mathrm{mM} \mathrm{NMDG}$, respectively. (B) Summary data indicating that the berberine-induced increase in the intracellular Ca ${ }^{2+}$ level in a buffer containing $62.5 \mathrm{mM} \mathrm{NaCl}$ was smaller than that in a buffer containing $125 \mathrm{mM} \mathrm{NaCl}$. The numbers of repeats are as follows: vehicle control of $300 \mu \mathrm{M}$ Ber, $\mathrm{n}=42$, $\mathrm{N}=3 ; 300 \mu \mathrm{M}$ Ber, $\mathrm{n}=58, \mathrm{~N}=3$; vehicle control of $300 \mu \mathrm{M}$ Ber in the $\mathrm{K}-\mathrm{H}$ buffer containing $62.5 \mathrm{mM} \mathrm{NaCl}, \mathrm{n}=24, \mathrm{~N}=3 ; 300 \mu \mathrm{M}$ Ber in the K-H buffer containing $62.5 \mathrm{mM} \mathrm{NaCl}, \mathrm{n}=21, \mathrm{~N}=3 ; \mathrm{n}$ and $\mathrm{N}$ are the numbers of $\mathrm{LV}$ myocytes and rats, respectively. Ber stands for berberine. ${ }^{* *} p<0.001$ vs. vehicle control group;

$\# \#<0.001$ vs. Ber-treated group in the modified K-H buffer containing $125 \mathrm{mM} \mathrm{NaCl}$; two-way ANOVA with Tukey's multiple comparisons test.

berberine-induced tension increase in LVM strips was dependent on the extracellular $\mathrm{Na}^{+}$.

The acutely isolated cardiomyocytes are depolarized, and their intracellular $\mathrm{Na}^{+}$level is elevated (Yao et al., 1998; Despa et al., 2002). The $\mathrm{Na}^{+}$influx during the action potential activated reverse NCX and promoted the $\mathrm{Ca}^{2+}$ entry in cardiomyocytes and neurons (Czyz and Kiedrowski, 2002; Larbig et al., 2010; Yan et al., 2015). The removal of extracellular $\mathrm{Na}^{+}$inhibits the increase in the intracellular $\mathrm{Ca}^{2+}$ level of human epidermoid carcinoma A-431 cells by $\mathrm{NaCN}$ (Kiang and Smallridge, 1994). The current study also showed that the reduction in the $\mathrm{Na}^{+}$concentration in the buffer suppressed the elevation of the intracellular $\mathrm{Ca}^{2+}$ level in $\mathrm{LV}$ myocytes by berberine (Figure 12). A previous study showed that berberine increased myocardial contractility and cardiac output via interrelated mechanisms, including the lengthening of ventricular action potential duration, which was partially due to stimulating the reverse mode of NCX (Wang and Zheng, 1997; Lau et al., 2001). The data presented here indicated that berberine increased the tension of LVM strips via a $\mathrm{Na}^{+}$-dependent $\mathrm{Ca}^{2+}$ entry, which might be through activating the reverse mode of NCX.

\section{CONCLUSION}

The current study revealed that berberine elevated the intracellular $\mathrm{Ca}^{2+}$ level in $\mathrm{LV}$ myocytes by increasing $\mathrm{Ca}^{2+}$ influx. It consequently increased the LV contractility. These were extracellular $\mathrm{Na}^{+}$-dependent.

\section{DATA AVAILABILITY STATEMENT}

All datasets generated for this study are included in the article/ supplementary material.

\section{ETHICS STATEMENT}

The animal study was reviewed and approved by College of Pharmaceutical Sciences, Southwest University, Chongqing, China. 


\section{AUTHOR CONTRIBUTIONS}

WX, YW, and JZ contributed to the study design. JZ, YW, and YJ carried out literature research. JZ, YW, JG and YJ performed experiments. WX, JZ, YW and JG contributed to data analysis. WX, JZ, and YW contributed to manuscript preparation and manuscript revision. The first two authors contributed equally to the manuscript.

\section{REFERENCES}

Affuso, F., Mercurio, V., Fazio, V., and Fazio, S. (2010). Cardiovascular and metabolic effects of Berberine. World J. Cardiol. 2 (4), 71-77. doi: 10.4330/ wjc.v2.i4.71

Bell, R. M., Mocanu, M. M., and Yellon, D. M. (2011). Retrograde heart perfusion: the Langendorff technique of isolated heart perfusion. J. Mol. Cell Cardiol. 50 (6), 940-950. doi: 10.1016/j.yjmcc.2011.02.018

Bers, D. M. (2002). Cardiac excitation-contraction coupling. Nature 415 (6868), 198-205. doi: 10.1038/415198a

Blaustein, M. P., and Lederer, W. J. (1999). Sodium/calcium exchange: its physiological implications. Physiol. Rev. 79 (3), 763-854. doi: 10.1152/physrev.1999.79.3.763

Bombardini, T. (2005). Myocardial contractility in the echo lab: molecular, cellular and pathophysiological basis. Cardiovasc. Ultrasound 3, 27. doi: 10.1186/1476-7120-3-27

Carre, G., Carreyre, H., Ouedraogo, M., Becq, F., Bois, P., Thibaudeau, S., et al. (2014). The hypotensive agent dodoneine inhibits L-type $\mathrm{Ca}^{2+}$ current with negative inotropic effect on rat heart. Eur. J. Pharmacol. 728, 119-127. doi: 10.1016/j.ejphar.2014.01.059

Chen, W., Wang, R., Chen, B., Zhong, X., Kong, H., Bai, Y., et al. (2014). The ryanodine receptor store-sensing gate controls $\mathrm{Ca}^{2+}$ waves and $\mathrm{Ca}^{2+}$-triggered arrhythmias. Nat. Med. 20 (2), 184-192. doi: 10.1038/nm.3440

Czyz, A., and Kiedrowski, L. (2002). In depolarized and glucose-deprived neurons, $\mathrm{Na}^{+}$influx reverses plasmalemmal $\mathrm{K}^{+}$-dependent and $\mathrm{K}^{+}$-independent $\mathrm{Na}^{+}$/ $\mathrm{Ca}^{2+}$ exchangers and contributes to NMDA excitotoxicity. J. Neurochem. 83 (6), 1321-1328. doi: 10.1046/j.1471-4159.2002.01227.x

Despa, S., Islam, M. A., Pogwizd, S. M., and Bers, D. M. (2002). Intracellular $\left[\mathrm{Na}^{+}\right]$ and $\mathrm{Na}^{+}$pump rate in rat and rabbit ventricular myocytes. J. Physiol. 539 (Pt 1), 133-143. doi: 10.1113/jphysiol.2001.012940

Eisner, D. A., Caldwell, J. L., Kistamas, K., and Trafford, A. W. (2017). Calcium and Excitation-Contraction Coupling in the Heart. Circ. Res. 121 (2), 181-195. doi: 10.1161/CIRCRESAHA.117.310230

Galindo-Tovar, A., and Kaumann, A. J. (2008). Phosphodiesterase-4 blunts inotropism and arrhythmias but not sinoatrial tachycardia of (-)-adrenaline mediated through mouse cardiac beta(1)-adrenoceptors. Br. J. Pharmacol. 153 (4), 710-720. doi: 10.1038/sj.bjp.0707631

Gilbert, G., Demydenko, K., Dries, E., Puertas, R. D., Jin, X., Sipido, K., et al. (2020). Calcium Signaling in Cardiomyocyte Function. Cold Spring Harb Perspect. Biol. 12 (3), 1-29. doi: 10.1101/cshperspect.a035428

Huang, H., Xie, M., Gao, L., Zhang, W., Zhu, X., Wang, Y., et al. (2019). Rolipram, a PDE4 Inhibitor, Enhances the Inotropic Effect of Rat Heart by Activating SERCA2a. Front. Pharmacol. 10, 221. doi: 10.3389/fphar.2019.00221

Jaleel, N., Nakayama, H., Chen, X., Kubo, H., MacDonnell, S., Zhang, H., et al. (2008). $\mathrm{Ca}^{2+}$ influx through T- and L-type $\mathrm{Ca}^{2+}$ channels have different effects on myocyte contractility and induce unique cardiac phenotypes. Circ. Res. 103 (10), 1109-1119. doi: 10.1161/CIRCRESAHA.108.185611

Jiang, M., Murias, J. M., Chrones, T., Sims, S. M., Lui, E., and Noble, E. G. (2014). American ginseng acutely regulates contractile function of rat heart. Front. Pharmacol. 5, 43. doi: 10.3389/fphar.2014.00043

Johnson, D. M., and Antoons, G. (2018). Arrhythmogenic Mechanisms in Heart Failure: Linking beta-Adrenergic Stimulation, Stretch, and Calcium. Front. Physiol. 9, 1453. doi: 10.3389/fphys.2018.01453

Kang, J., Chen, X. L., Ji, J., Lei, Q., and Rampe, D. (2012). Ca ${ }^{2+}$ channel activators reveal differential L-type $\mathrm{Ca}^{2+}$ channel pharmacology between native and stem cell-derived cardiomyocytes. J. Pharmacol. Exp. Ther. 341 (2), 510-517. doi: 10.1124/jpet.112.192609

\section{ACKNOWLEDGMENTS}

The authors are grateful for the support of the manuscript revision to all the members of our team and Dr. Xian-Min Yu. This work was supported by Funding from Southwest University (Grant number SWU 115086, 104290/22300503) and Administration of Foreign Experts Affairs of China (Grant number BC2018042).

Kiang, J. G., and Smallridge, R. C. (1994). Sodium cyanide increases cytosolic free calcium: evidence for activation of the reversed mode of the $\mathrm{Na}^{+} / \mathrm{Ca}^{2+}$ exchanger and $\mathrm{Ca}^{2+}$ mobilization from inositol trisphosphate-insensitive pools. Toxicol. Appl. Pharmacol. 127 (2), 173-181. doi: 10.1006/taap.1994.1151

Larbig, R., Torres, N., Bridge, J. H., Goldhaber, J. I., and Philipson, K. D. (2010). Activation of reverse $\mathrm{Na}^{+}-\mathrm{Ca}^{2+}$ exchange by the $\mathrm{Na}^{+}$current augments the cardiac $\mathrm{Ca}^{2+}$ transient: evidence from NCX knockout mice. J. Physiol. 588 (Pt 17), 3267-3276. doi: 10.1113/jphysiol.2010.187708

Lau, C. W., Yao, X. Q., Chen, Z. Y., Ko, W. H., and Huang, Y. (2001). Cardiovascular actions of berberine. Cardiovasc. Drug Rev. 19 (3), 234-244. doi: 10.1111/j.1527-3466.2001.tb00068.x

Li, Y., Ren, G., Wang, Y. X., Kong, W. J., Yang, P., Wang, Y. M., et al. (2011). Bioactivities of berberine metabolites after transformation through CYP450 isoenzymes. J. Transl. Med. 9, 62. doi: 10.1186/1479-5876-9-62

Nakao, S., Wakabayashi, S., and Nakamura, T. Y. (2015). Stimulus-dependent regulation of nuclear $\mathrm{Ca}^{2+}$ signaling in cardiomyocytes: a role of neuronal calcium sensor-1. PloS One 10 (4), e0125050. doi: 10.1371/journal.pone.0125050

Philipson, K. D., and Nicoll, D. A. (2000). Sodium-calcium exchange: a molecular perspective. Annu. Rev. Physiol. 62, 111-133. doi: 10.1146/annurev.physiol.62.1.111

Roth, G. M., Bader, D. M., and Pfaltzgraff, E. R. (2014). Isolation and physiological analysis of mouse cardiomyocytes. J. Vis. Exp. (91), e51109. doi: $10.3791 / 51109$

Sanchez-Chapula, J. (1996). Increase in action potential duration and inhibition of the delayed rectifier outward current IK by berberine in cat ventricular myocytes. $\mathrm{Br}$. J. Pharmacol. 117 (7), 1427-1434. doi: 10.1111/j.1476-5381.1996.tb15302.x

Shaffer, J. E. (1985). Inotropic and chronotropic activity of berberine on isolated guinea pig atria. J. Cardiovasc. Pharmacol. 7 (2), 307-315. doi: 10.1097/ 00005344-198503000-00016

Sola, R., Valls, R. M., Puzo, J., Calabuig, J. R., Brea, A., Pedret, A., et al. (2014). Effects of poly-bioactive compounds on lipid profile and body weight in a moderately hypercholesterolemic population with low cardiovascular disease risk: a multicenter randomized trial. PloS One 9 (8), e101978. doi: 10.1371/ journal.pone.0101978

Song, M., Chen, D., and Yu, S. P. (2014). The TRPC channel blocker SKF 96365 inhibits glioblastoma cell growth by enhancing reverse mode of the $\mathrm{Na}^{+} / \mathrm{Ca}^{2+}$ exchanger and increasing intracellular $\mathrm{Ca}^{2+}$. Br. J. Pharmacol. 171 (14), 3432 3447. doi: 10.1111/bph.12691

Tan, X. S., Ma, J. Y., Feng, R., Ma, C., Chen, W. J., Sun, Y. P., et al. (2013). Tissue distribution of berberine and its metabolites after oral administration in rats. PloS One 8 (10), e77969. doi: 10.1371/journal.pone.0077969

Tang, T., Duffield, R., and Ho, A. K. (1998). Effects of $\mathrm{Ca}^{2+}$ channel blockers on $\mathrm{Ca}^{2+}$ loading induced by metabolic inhibition and hyperkalemia in cardiomyocytes. Eur. J. Pharmacol. 360 (2-3), 205-211. doi: 10.1016/s00142999(98)00657-8

Tilley, D. G., Zhu, W., Myers, V. D., Barr, L. A., Gao, E., Li, X., et al. (2014). betaadrenergic receptor-mediated cardiac contractility is inhibited via vasopressin type 1A-receptor-dependent signaling. Circulation 130 (20), 1800-1811. doi: 10.1161/CIRCULATIONAHA.114.010434

Uhl, S., Freichel, M., and Mathar, I. (2015). Contractility Measurements on Isolated Papillary Muscles for the Investigation of Cardiac Inotropy in Mice. J. Vis. Exp. (103), e53076. doi: 10.3791/53076

Wang, Y. X., and Zheng, Y. M. (1997). Ionic mechanism responsible for prolongation of cardiac action-potential duration by berberine. J. Cardiovasc. Pharmacol. 30 (2), 214-222. doi: 10.1097/00005344199708000-00010 
Xin, W. K., Kwan, C. L., Zhao, X. H., Xu, J., Ellen, R. P., McCulloch, C. A., et al. (2005). A functional interaction of sodium and calcium in the regulation of NMDA receptor activity by remote NMDA receptors. J. Neurosci. 25 (1), 139148. doi: 10.1523/JNEUROSCI.3791-04.2005

Xu, S. Z., Zhang, Y., Ren, J. Y., and Zhou, Z. N. (1997). Effects of berberine of Land T-type calcium channels in guinea pig ventricular myocytes. Zhongguo Yao Li Xue Bao 18 (6), 515-518.

Yan, Z. Y., Ban, T., Fan, Y., Chen, W. R., Sun, H. L., Chen, H., et al. (2015). $\mathrm{Na}^{+}$-induced $\mathrm{Ca}^{2+}$ influx through reverse mode of $\mathrm{Na}^{+}-\mathrm{Ca}^{2+}$ exchanger in mouse ventricular cardiomyocyte. Oncotarget 6 (27), 23272-23280. doi: 10.18632/oncotarget.4878

Yao, A., Su, Z., Nonaka, A., Zubair, I., Lu, L., Philipson, K. D., et al. (1998). Effects of overexpression of the $\mathrm{Na}^{+}-\mathrm{Ca}^{2+}$ exchanger on $\left[\mathrm{Ca}^{2+}\right]_{\mathrm{i}}$ transients in murine ventricular myocytes. Circ. Res. 82 (6), 657-665. doi: 10.1161/ 01.res.82.6.657

Yuan, L., Tu, D., Ye, X., and Wu, J. (2006). Hypoglycemic and hypocholesterolemic effects of Coptis chinensis franch inflorescence. Plant Foods Hum. Nutr. 61 (3), 139-144. doi: 10.1007/s11130-0060023-7
Zeng, X., and Zeng, X. (1999). Relationship between the clinical effects of berberine on severe congestive heart failure and its concentration in plasma studied by HPLC. BioMed. Chromatogr. 13 (7), 442-444. doi: 10.1002/(SICI)1099-0801 (199911) 13:7<442::AID-BMC908>3.0.CO;2-A

Zeng, X. H., Zeng, X. J., and Li, Y. Y. (2003). Efficacy and safety of berberine for congestive heart failure secondary to ischemic or idiopathic dilated cardiomyopathy. Am. J. Cardiol. 92 (2), 173-176. doi: 10.1016/s0002-9149 (03)00533-2

Conflict of Interest: The authors declare that the research was conducted in the absence of any commercial or financial relationships that could be construed as a potential conflict of interest.

Copyright (C) 2020 Zhao, Wang, Gao, Jing and Xin. This is an open-access article distributed under the terms of the Creative Commons Attribution License (CC BY). The use, distribution or reproduction in other forums is permitted, provided the original author(s) and the copyright owner(s) are credited and that the original publication in this journal is cited, in accordance with accepted academic practice. No use, distribution or reproduction is permitted which does not comply with these terms. 